\title{
A Research on Whey as a Renewable Substrate for Single Cell Oil Production by Saprolegnia diclina
}

\author{
Arzu Akpinar-Bayizit, Tulay Ozcan, Lutfiye Yilmaz-Ersan, and Fikri Basoglu
}

\begin{abstract}
The objective of the present laboratory scale experiment was to assess utilization of cheese whey by Saprolegnia diclina IMI 318623 for biomass and lipid production. Current interest in single cell oils (SCOs) accumulated by oleaginous fungi centers around the ability of these microorganisms to convert agro-industrial surpluses and residues into lipids as potential alternative to edible plant and/or animal lipids, lipids containing polyunsaturated fatty acids (PUFAs) or biodiesel. The results indicated that Saprolegnia diclina can utilize whey for biomass and lipid accumulation, however, cannot adequately synthesize long chain PUFAs probably due to depletion of specific $\omega 3$ fatty acid desaturases and elongases.
\end{abstract}

Index Terms-Saprolegnia, single cell oil, polyunsaturated fatty acids, whey.

\section{INTRODUCTION}

Dairy industries generate significant liquid wastes, of which, cheese whey is the most abundant. Cheese whey, also called as serum or milk permeate, is the yellow-green liquid that remains after milk has been precipitated during cheese manufacture [1].

Rennet or an edible acid is added to the heated milk which results in milk coagulation and separation of the milk solids from the liquid whey to produce cheese [2]. The chemical composition of whey varies according to the type of milk used, the variety of cheese produced and the cheesemaking process employed [1]. Typically, cheese whey is a fairly dilute product with a total solids of 5-8\% comprising proteins $(10-20 \%)$, lactose $(60-80 \%)$, fat $(3 \%)$, minerals $(8 \%)$, vitamins, lactic acid and trace elements [3].

Cheese whey is produced in very high and constantly increasing quantities [4]. The world production of cheese whey is estimated at over $10^{8}$ tonnes per year creating disposal problems and an important addition to environmental pollution due to its high organic load with a loss of milk constituents of excellent bioactive value [5]-[9].

In recent years, a growing awareness regarding the environmental problems caused by whey and its nutritional value combined the considerable efforts to utilize cheese whey for microbial growth for the production of addedvalue compounds through fermentation processes besides reduced environmental pollution [8], [10], [11].

Manuscript received February 5, 2015; revised April 22, 2015. This work was supported by a TÜBİTAK, TOVAG-105 O 041 and Commission of Scientific Research Projects of Uludag University, Bursa, Turkey (Z2002/11).

The authors are with the Department of Food Engineering, Faculty of Agriculture, Uludag University, Bursa, Turkey (e-mail: abayizit@uludag.edu.tr, tulayozcan@uludag.edu.tr, lutfiyey@uludag.edu.tr, fbasoglu@uludag.edu.tr).
The lactose content and the presence of other essential nutrients for microbial growth make whey a potential microbial feedstock [12].

Besides bio-ethanol fermentation and production of fermented beverages [13]-[18] conversion into microbial mass and microbial lipids (so called "single cell oil"; SCOs) has also been considered as an interesting alternative for cheese whey valorisation.

Oils and fats are both classed as lipids, substances of vegetable and animal origin that widely found in nature and form the third major group of macronutrients after proteins and carbohydrates [19]. Lipids have many metabolic roles, for example, they act as storage materials in animals, plant and microbial cells and are also responsible for the structure of cell membranes, and protect the body against cold and other environmental influences, etc. Though the human body can produce saturated and mono-unsaturated fatty acids from food components, it cannot synthesize polyunsaturated fatty acids. In other words, these have to be supplied externally from specific foodstuffs such as leafy vegetables and fish. This explains why polyunsaturated fatty acids are called "essential fatty acids" [20].

Approximately $80 \%$ of the world's oil and fat need is derived from agricultural products, and the remainder coming from animal and marine sources. It is essential to find new sources for oil and protein supplement with concern to the nutritional problems accompanying the rapid growth of world's population. In fear of the depletion of oil resources and the global warming, present biotechnological research has concentrated on the commercial exploitation of microorganisms for the production of fuels and chemical materials [21]. The biotechnological production of SCO has been focused on the ability of various oleaginous microorganisms to convert agro-industrial wastes or raw materials into specialty lipids rarely found in the plant or animal kingdom like substitutes of cocoa-butter [21]-[26] or equivalents of plant oils that contain "rare" polyunsaturated fatty acids (PUFAs) of nutritional and pharmaceutical importance, like gamma-linolenic acid (GLA-D6,9,12C18:3) [27]-[36]. Microbial oils have limited potential as substitutes for plant and animal edible oils and fats because they are generally more expensive than agricultural products. Thus, recently, the focus changed from competing with conventional lipid sources to more expensive lipid products with medical applications such as certain polyunsaturated long-chain fatty acids as well as hydroxy polyunsaturated fatty acids, i.e. prostaglandins, leukotrienes and thromboxanes [21]. Besides the production ofspecialty lipids, worth mentioning is the potential future use ofmicrobial oil derived from oleaginous microorganisms as a nonconventional substitute of the various routinely used 
seed oils (e.g. rapeseed oil) for the production of " 2 nd generation"' biodiesel [37]-[40].

Saprolegnia is a genus of freshwater mould, often called as "cotton mould" due to its characteristic white or grey filaments. Eventhough generally described as a secondary pathogen leading to Saprolegniosis, a widespread fungal disease in fish, Saprolegnia diclina has been known as an EPA-rich fungus [41]-[43]. Pereira et al. [44] have reported the presence of $\omega-3$ fatty acid desaturase in Saprolegnia diclina, which might be responsible for EPA production. Here we aimed to investigate the biomass and fat production by Saprolegnia diclina cultivated on whey utilized as renewable carbon substrate and liquid medium.

\section{MATERIALS AND METHODS}

\section{A. Fungal Cultivation and Preparation of Inoculum}

The examined fungal culture of Saprolegnia diclina IMI 318623 provided from the culture collections of International Mycological Institute, Surrey, UK, was maintained on potato dextrose agar (PDA, Difco) slants at $4 \pm 1{ }^{\circ} \mathrm{C}$ and subcultured every month till further use. The inocula were prepared from the stock cultures on PDA slants. Approximately $1 \mathrm{~cm}^{2}$ of mycelia, grown for 4 days on PDA slants, was aseptically removed and used as the inoculum. Each starter culture flask contained $50 \mathrm{~mL}$ of basic medium, consisting $\left(\mathrm{gL}^{-1}\right) ; \mathrm{KH}_{2} \mathrm{PO}_{4}, 7 ; \mathrm{Na}_{2} \mathrm{HPO}_{4}, 2$; yeast extract, 1.5; ammonium chloride, 2; glucose, 10; and trace element solution, $2 \mathrm{~mL}$. The trace element solution contains $\left(\mathrm{gL}^{-1}\right) ; \mathrm{CaCl}_{2} \cdot 2 \mathrm{H}_{2} \mathrm{O}, 0.5 ; \mathrm{FeSO}_{4} \cdot 7 \mathrm{H}_{2} \mathrm{O}, 0.1$, $\mathrm{ZnSO}_{4} \cdot 7 \mathrm{H}_{2} \mathrm{O}, 0.1 ; \mathrm{MnSO}_{4} \cdot 2 \mathrm{H}_{2} \mathrm{O}, 0.001 ; \mathrm{CuSO}_{4} \cdot 5 \mathrm{H}_{2} \mathrm{O}$, 0.005 . The $\mathrm{pH}$ of the media was adjusted to 6.0 using $1 \mathrm{~N}$ $\mathrm{KOH}$ and sterilized at $121^{\circ} \mathrm{C}$ for 15 minutes.

\section{B. Growth Media and Fungal Growth}

To examine the growth of Saprolegnia diclina on whey glucose, the main carbon source in basic medium, was exchanged with whey powder $\left(20 \mathrm{gL}^{-1}\right)$. The composition of whey powder is given in Table I.

TABLE I: THE COMPOSITION OF WHEY POWDER EMPLOYED IN THE PRESENT WORK

\begin{tabular}{|c|c|}
\hline Lactose $(\%)$ & 75.5 \\
\hline $\mathrm{pH}$ & $6.3-6.8$ \\
\hline Titritable acidty (LA\%) & 0.18 \\
\hline Fat $(\%)$ & 1.5 \\
\hline Protein $(\%)$ & 12 \\
\hline $\operatorname{Ash}(\%)$ & 8 \\
\hline Solubility index ( $\mathrm{mL})$ & 1.25 \\
\hline Moisture (\%) & 3 \\
\hline
\end{tabular}

The initial $\mathrm{pH}$ of growth medium was adjusted to 6.0-6.5 and sterilized at $121{ }^{\circ} \mathrm{C}$ for 15 minutes in order to denaturate proteins. This was done to eliminate excess nitrogen from the growth circumstances. The denaturated protein was vacuum filtered, the $\mathrm{pH}$ of the supernatant (growth medium with peptonized whey) was adjusted to 6.0, and re-sterilized at $121{ }^{\circ} \mathrm{C}$ for 15 minutes [19]. The inocula, pre-cultivated for $48 \mathrm{~h}$, were transferred into $2 \mathrm{~L}$ Erlenmeyer flasks containing $1000 \mathrm{~mL}$ growth medium, which were orbitally shaken at $160 \mathrm{rpm}$. The batch cultivation was carried out at $25 \pm 1{ }^{\circ} \mathrm{C}$ until the carbon was totally exhausted (Fig. 1).

\section{Harvesting and Lipid Extraction}

Fungal cells were harvested according to Akpinar [19] and lipid content was determined by Folch et al. [45]. All of the experiments were performed in duplicate (Fig. 1).

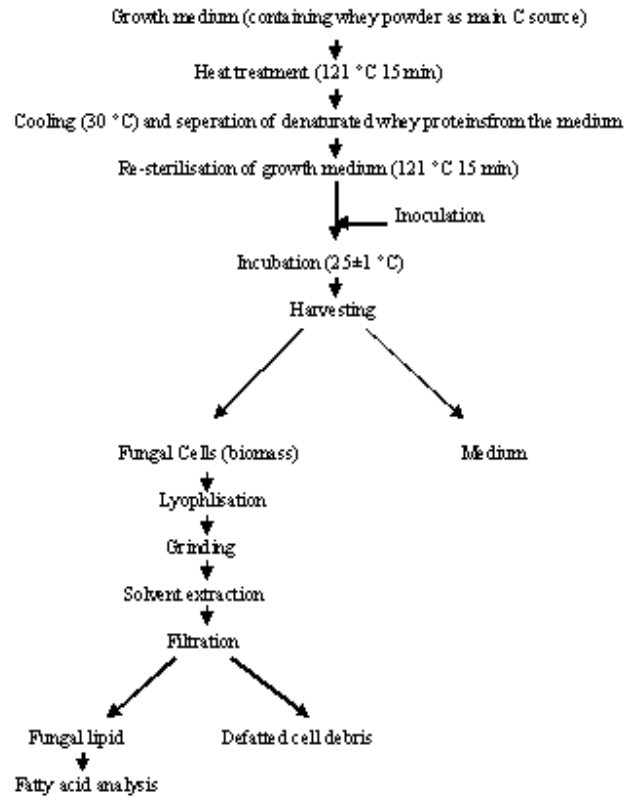

Fig. 1. The schematic of whey utilization for microbial lipid production.

\section{Preparation of Fatty Acid Methyl Esters}

Cold esterification was carried out to obtain fatty-acid methyl esters (FAMES) of the algal lipids according to the IUPAC (International Union of Applied and Pure Chemistry) method [46]. The analysis of fatty acid was performed with Perkin-Elmer-Thermoquest Trace Gas Chromatograph (GC) coupled with Perkin-Elmer-Thermoquest Trace mass spectroscopy (MS) detector. A fused silica capillary column, SP-2330 $(30 \mathrm{~m} \times 0.25 \mathrm{~mm}$ inside diameter, $0.25 \mu \mathrm{m}$ film thickness) was used for $\mathrm{GC}$ system. The temperature program was set up from $50{ }^{\circ} \mathrm{C}$ to $220{ }^{\circ} \mathrm{C}$ with a ramp of $5{ }^{\circ} \mathrm{C} \mathrm{min}{ }^{-1}$, of $8 \mathrm{~min}$ isotherm at $120^{\circ} \mathrm{C}$ and $220{ }^{\circ} \mathrm{C}$. Both the injector and detector temperatures were $250{ }^{\circ} \mathrm{C}$.

Helium was used as the carrier gas $\left(1 \mathrm{~mL} \mathrm{~min}^{-1}\right)$. The injection volume was $0.5 \mu \mathrm{L}$ with a split rate of 150:1. For the MS detection interface temperature was $230{ }^{\circ} \mathrm{C}$, an ionization energy (EI) of $70 \mathrm{eV}$, full scan acquisition mode, a source temperature of $150{ }^{\circ} \mathrm{C}$, scan range of 50-300 amu and scan rate of $1 \mathrm{~s}^{-1}$ were used.

\section{RESULTS AND DISCUSSION}

Organisms, principally eukaryotes, which can accumulate $20 \%$ or more of their biomass as lipid have been termed as "oleaginous" in keeping with oil-bearing plants that are similarly named. Not all microorganisms can be considered as oleaginous since they contain lipids for the essential functioning of membranes and membranous structures like all living cells. The accumulation of lipid in oleaginous molds is known to occur when there is a depletion of growth nutrients, other than carbon, preventing cell proliferation and allowing the accumulation of lipids in the cells [41].

As Saprolegnia diclina is reported as a good producer of 
EPA the research has particularly focused on pathways and genes responsible in EPA synthesis. Thus the data on biomass, lipid production and fatty acid production using food industry wastes is limited. Whey can serve as a good substrate for microbial growth and waste valuation as comprising ingredients necessary for microbial fermentations. This is the first report focusing on Saprolegnia diclina with respect to lipid and fatty acid production using whey as carbon source, which is particularly known as a good carbon source for yeast cultivation in sense of accumulation of high-value $\omega-3$ fatty acids.

Saprolegnia diclina realized a high biomass $\left(2.28 \mathrm{~g} \mathrm{~L}^{-1}\right)$

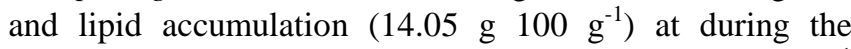
cultivation on whey media than basic media $\left(3.9 \mathrm{~g} \mathrm{~L}^{-1}\right.$

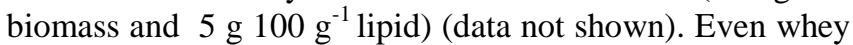
was thought to be a good carbon substrate for SCO production due to its lactose content, most of the work were related to biomass and lipid accumulation with yeasts than fungi [47]-[49].

The results indicated that Saprolegnia diclina did ferment whey as yeast starins and accumulated a significant amount of lipid in the cells. We have observed that lipid contents in wet biomass of some Fusarium species were between 67.5 and $221.25 \mathrm{mg}$ and $F$. graminearum had the highest content of lipid in wet biomass with $86.61 \%$, followed by $F$. semitectum $(80.60 \%)$. From both observations, it is clear that whey could be employed for lipid production by fungal species.

The fatty acid composition of total lipids determined by capillary gas chromatography, as well as total lipid contents of S. diclina are presented in Table II. The chromatographic analysis revealed an array of both saturated and unsaturated fatty acids. The data indicated the presence of identified 13 fatty acid compounds with different chain lengths (Fig. 2 and Table III). The saturated and unsaturated portions represented $30.93 \%$ to $60.77 \%$ of total fatty acids, respectively. The amount of MUFAs to PUFAs was 53.25:7.52. This ratio was significantly different than lipid of $S$. diclina grown on basic medium since MUFAs : PUFAs was 26.09:36.14.

The most abundant unsaturated fatty acids were oleic acid $(50.98 \%)$ and linoleic acid $(7.01 \%)$. On whey oleic acid content increased 2-folds whereas linoleic acid value decreased almost 2-folds. S. diclina is stated as a good producer of EPA due to specific $\omega 3$ fatty acid desaturase, however, on whey the fungus couldnot produce long-chain PUFAs probably due to depletion of characteristic destaurases and elongases. Long-chain polyunsaturated fatty acids (LCPUFAs), especially $\omega-3 \quad$ LCPUFAs eicosapentanoic acid (EPA) and docosahexanoic acid (DHA), are essential nutrients critical to human nutrition and health.

TABLE II: THE FATTY ACID COMPOSITION OF SAPROLEGNIA DICLINA GROWN ON GLUCOSE AND WHEY BASED MEDIA

\begin{tabular}{|c|c|c|}
\hline Fatty Acids (\%) & Basic media & $\begin{array}{c}\text { Whey } \\
\text { supplemeted } \\
\text { media }\end{array}$ \\
\hline $\begin{array}{l}\text { Less than } 16 \text { carbons } \\
\text { Saturated }\end{array}$ & 10.23 & 2.51 \\
\hline C16:0 & 14.47 & 21.84 \\
\hline C18:0 & 11.34 & 8.67 \\
\hline C20:0 & nd & 0.42 \\
\hline \multicolumn{3}{|l|}{ Unsaturated } \\
\hline \multicolumn{3}{|l|}{ Monounsaturated } \\
\hline C16:1, cis-9 & 1.01 & 2.27 \\
\hline C18:1, cis-9 & 25.08 & 50.98 \\
\hline C18:1, trans-9 & nd & nd \\
\hline \multicolumn{3}{|l|}{ Polyunsaturated } \\
\hline C18:2, cis $-9,12$ & 15.41 & 7.01 \\
\hline C18:2, trans-9,12 & nd & 0.02 \\
\hline $\begin{array}{l}\text { C18:3, cis-9,12,15 ( } \alpha \text { - } \\
\text { LNA) }\end{array}$ & nd & 0.03 \\
\hline C18:3, cis-6,9,12 $(\gamma$-LNA $)$ & 1.05 & 0.04 \\
\hline $\mathrm{C} 20: 3$, cis $-5,8,11$ & nd & 0.37 \\
\hline 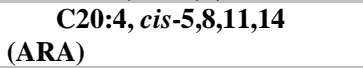 & 10.17 & 0.01 \\
\hline $\begin{array}{l}\text { C20:5, cis-5,8,11,14,17 } \\
\text { (EPA) }\end{array}$ & 9.51 & 0.04 \\
\hline Unidentified & 7.26 & 5.82 \\
\hline Saturated $(\%)$ & 25.81 & 30.93 \\
\hline Unsaturated (\%) & 56.23 & 60.77 \\
\hline $\begin{array}{l}\text { Monounsaturated: } \\
\text { Polyunsaturated }\end{array}$ & $26.09: 36.14$ & $53.25: 7.52$ \\
\hline
\end{tabular}

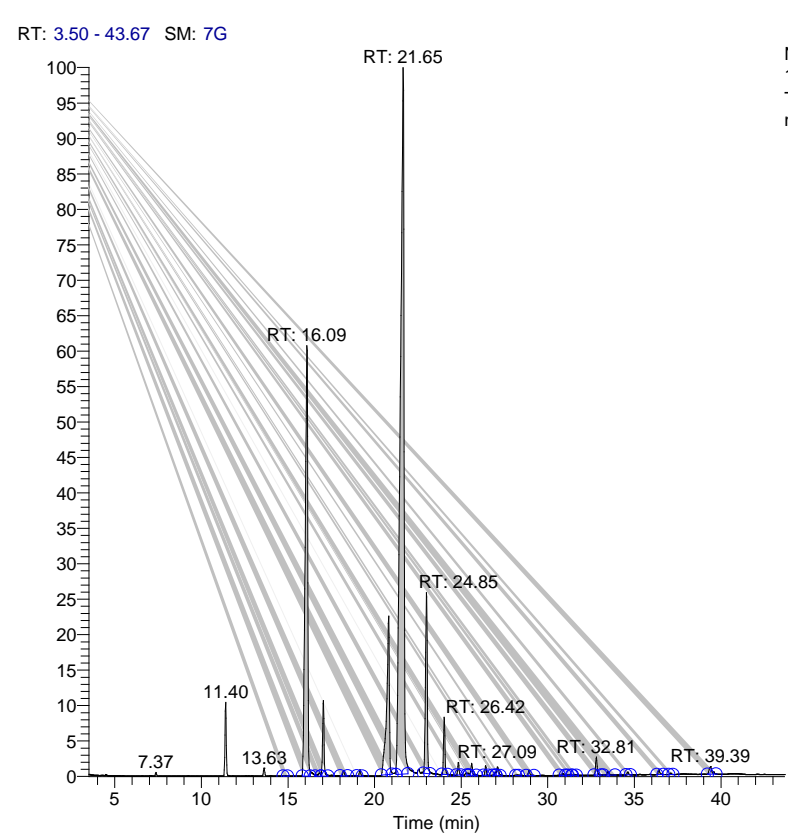

Fig. 2. The GC-MS chromatogram for Saprolegnia diclina.

TABLE III: THE M/Z VALUES FOR SAPROLEGNIA DICLINA

\begin{tabular}{|c|c|c|}
\hline RT & Fatty acid methyl ester & $\mathbf{m} / \mathbf{z}$ values \\
\hline 14.85 & $\begin{array}{l}\text { Hexadecanoic acid, methyl ester } \\
\text { (palmitic acid) }\end{array}$ & $\begin{array}{c}270,239,227,213,199,185,171,143,129,87 \\
74,55,43,29\end{array}$ \\
\hline 16.09 & $\begin{array}{l}\text { Hexadecanoic acid, methyl ester } \\
\text { (palmitic acid) }\end{array}$ & $\begin{array}{c}270,239,227,213,199,185,171,143,129,87 \\
74,55,43,29\end{array}$ \\
\hline 16.82 & $\begin{array}{l}\text { Hexadecanoic acid, methyl ester } \\
\text { (palmitic acid) }\end{array}$ & $\begin{array}{c}270,239,227,213,199,185,171,143,129,87 \\
74,55,43,29\end{array}$ \\
\hline 17.05 & 9-Hexadecenoic acid, methyl ester, (Z)- (CAS) (palmitoleic acid) & $268,236,218,194,152,97,87,74,55,43,41,39$ \\
\hline 18.21 & $\begin{array}{l}\text { Heptadecanoic acid, methyl ester (CAS) } \\
\text { (margaric acid) }\end{array}$ & $\begin{array}{c}284,253,241,227,199,185,157,143,129,97 \\
87,74,55,43,41,29\end{array}$ \\
\hline
\end{tabular}




\begin{tabular}{|c|c|c|}
\hline 19.14 & Cyclopropaneoctanoic acid, 2-hexyl-, methyl ester & $\begin{array}{c}282,250,232,208,185,171,166,152,138,123, \\
111,96,83,74,69,55,43,41\end{array}$ \\
\hline 20.81 & $\begin{array}{c}\text { Octadecanoic acid, methyl ester (CAS) } \\
\text { (stearic acid) }\end{array}$ & $\begin{array}{c}298,267,255,241,227,199,185,157,143,129, \\
87,74,55,43,41,29\end{array}$ \\
\hline 21.65 & $\begin{array}{c}\text { 9-Octadecenoic acid, methyl ester } \\
\text { (oleic acid) }\end{array}$ & $\begin{array}{c}296,278,264,246,222,180,137,123,97,74, \\
55,43,41,29\end{array}$ \\
\hline 22.29 & 9,12-Octadecadienoic acid (Z,Z)-, methyl ester (CAS) (linoleic acid) & $\begin{array}{c}294,263,220,178,164,150,136,123,109,95 \\
81,67,55,43,41,39\end{array}$ \\
\hline 24.01 & 6,9,12-Octadecatrienoic acid, methyl ester (CAS) $(\gamma$-linolenic acid) & $\begin{array}{c}292,243,235,221,207,194,175,163,150,121, \\
107,93,79,67,55,43,41\end{array}$ \\
\hline 24.85 & $\begin{array}{l}\text { Eicosanoic acid, methyl ester (CAS) } \\
\text { (arachidic acid) }\end{array}$ & $\begin{array}{c}326,295,283,269,255,241,227,213,199,185, \\
171,157,143,129,107,97,87,74,55\end{array}$ \\
\hline 25.40 & $\begin{array}{c}\text { 9,12-Octadecadienoic acid (Z,Z)-, methyl ester } \\
\text { (linoleic acid) }\end{array}$ & $\begin{array}{c}294,263,220,178,164,150,136,123,109,95 \\
81,67,55,43,41,39\end{array}$ \\
\hline 25.60 & 11-Eicosenoic acid, methyl ester (CAS) & $\begin{array}{c}324,292,274,263,250,235,222,208,194,179, \\
152,139,125,97,83,74,69,55,41\end{array}$ \\
\hline 26.42 & $\begin{array}{l}\text { 9,12-Octadecadienoic acid (Z,Z)-, methyl ester (CAS) } \\
\text { (linoleic acid) }\end{array}$ & $\begin{array}{c}294,263,220,178,164,150,136,123,109,95, \\
81,67,55,43,41,39\end{array}$ \\
\hline 28.92 & $\begin{array}{l}\text { Docosanoic acid, methyl ester (CAS) } \\
\text { (behenic acid) }\end{array}$ & $\begin{array}{c}354,323,311,297,269,255,213,199,157,143, \\
129,97,87,74,55,43,41,29\end{array}$ \\
\hline 30.86 & Tricosanoic acid, methyl ester (CAS) & $\begin{array}{c}368,337,325,311,283,269,255,213,199,157, \\
143,129,97,87,74,55,43,41,29\end{array}$ \\
\hline 31.26 & $\begin{array}{c}\text { 6,9,12-Octadecatrienoic acid, methyl ester (CAS) } \\
(\gamma \text {-linolenic acid })\end{array}$ & $\begin{array}{c}292,243,235,208,194,175,163,150,121,107, \\
93,79,67,55,43,41\end{array}$ \\
\hline 31.57 & $\begin{array}{c}\text { 6,9,12-Octadecatrienoic acid, methyl ester (CAS) } \\
(\gamma \text {-linolenic acid })\end{array}$ & $\begin{array}{c}292,243,235,221,207,194,175,163,150,121, \\
107,93,79,67,55,43,41\end{array}$ \\
\hline 32.81 & $\begin{array}{c}\text { Tetracosanoic acid, methyl ester (CAS) } \\
\text { (lignoceric acid) }\end{array}$ & $\begin{array}{c}382,351,339,325,297,283,255,241,227,213, \\
185,157,143,97,87,74,57,43,41,29\end{array}$ \\
\hline 33.46 & 15-Tetracosenoic acid, methyl ester, (Z)- (CAS) & $\begin{array}{c}380,349,307,264,250,222,194,180,153,139, \\
125,111,97,83,74,69,55,41,29\end{array}$ \\
\hline 34.60 & Pentacosanoic acid, methyl ester (CAS) & $\begin{array}{c}396,365,353,311,297,241,227,199,185,157 \\
143,129,97,87,74,69,55,43,41\end{array}$ \\
\hline 36.42 & $\begin{array}{l}\text { Hexacosanoic acid, methyl ester } \\
\text { (cerotic acid) }\end{array}$ & $\begin{array}{c}410,367,325,311,255,241,199,185,143,129, \\
101,97,87,74,57,55,43,41,29\end{array}$ \\
\hline 37.07 & $\begin{array}{l}\text { Docos-13-enoic acid } \\
\quad \text { (erucic acid) }\end{array}$ & $\begin{array}{c}320,303,278,264,250,236,222,181,179,166, \\
152,139,125,111,98,97,84,83,82,70,69,67, \\
57,55,43,41,39,29\end{array}$ \\
\hline
\end{tabular}

\section{CONCLUSION AND POTENTIAL APPLICATIONS FOR SAPROLEGNIA DICLINA LIPIDS}

Nowadays, in the course of the ongoing endeavor to find alternatives for commercial oil supplies, significant effort has been put into expanding the utilization of renewable resources via microbial fermentations since there is already a considerable variety of by-products which can turn into value-added products such as biomass, lipids, pigments, enzymes. Interest in microbial lipids has been renewed as medical and nutritional research has revealed potential uses of microbial PUFAs, however there are many economic constraints. S. diclina showed a high growth and lipid accumulation on whey, but could not produce long chain PUFAs, instead accumulated very high amount of oleic acid which was very similar to plant oils such as olive oil, sunflower oil.

\section{REFERENCES}

[1] M. I. Gonzalez, "The biotechnological utilization of cheese whey: A review," Bioresource Technology, vol. 57, pp. 1-11, 1996.

[2] S. Andrea, "Cultures of Milk: The Biology and Meaning of Dairy Products in the United States and India," Cambridge, Massachusetts: Harvard University Press, p. 11, 2014.

[3] C. V. Morr, "Whey proteins: Manufacture," in Developments in Dairy Chemistry-4: Functional Milk Proteins, P. F. Fox, Ed. New York: Elsevier Appl. Sci, 1989, pp. 245-284.

[4] D. Peters, "Raw materials," Advances in Biochemical Engineering/Biotechnology, vol. 105, pp. 1-30, 2006.

[5] M. I. G. Siso, "The biotechnological utilization of cheese whey: A review," Bioresource Technology, vol. 57, pp. 1-11, 1996.
[6] S. Grba, V. Stehlik-Tomas, D. Stanzer, N. Vahcic, and A. Skrlin, "Selection of yeast strain Kluyveromyces marxianus for alcohol and biomass production on whey," Chemical and Biochemical Engineering, vol. 16, pp. 13-16, 2002.

[7] S. Ozmihci and F. Kargi, "Kinetics of batch ethanol fermentation of cheese-whey powder (CWP) solution as function of substrate and yeast concentrations," Bioresource Technology, vol. 98, pp. 29782984, 2007.

[8] P. M. R. Guimarães, J. A. Teixeira, and L. Domingues, "Fermentation of lactose to bio-ethanol by yeasts as part of integrated solutions for the valorisation of cheese whey," Biotechnology Advances, vol. 28, pp. 375-384, 2010.

[9] A. Yasmin, M. S. Butt, A. Sameen, and M. Shahid, "Physicochemical and amino acid profiling of cheese whey," Pakistan Journal of Nutrition, vol. 12, pp. 455-459, 2013.

[10] A. R. Madureira, C. I. Pereira, A. M. P. Gomes, M. E. Pintado, and F. X. Malcata, "Bovine whey proteins-overview on their main biological properties," Food Research International, vol. 40, pp. 1197-1211, 2007.

[11] M. B. Perez-Gago and J. M. Krochta, "Formation and properties of whey protein films and coatings," in Protein-Based Films And Coatings A. Gennadios, Ed. CRC Press, Boca Raton FL, USA, 2002, pp. $159-180$.

[12] P. S. Panesar, J. F. Kennedy, D. N. Gandhi, and K. Bunko, "Bioutilisation of whey for lactic acid production," Food Chemistry, vol. 105, pp. 1-14, 2007.

[13] S. Sansonetti, S. Curcio, V. Calabrò, and G. Iorio, "Bio-ethanol production by fermentation of ricotta cheese whey as an effective alternative non-vegetable source," Biomass and Bioenergy, vol. 33, pp. 1687-1692, 2009.

[14] A. E. Ghaly and A. A. El-Taweel, "Effect of micro-aeration on the growth of Candida pseudotropicalis and production of ethanol during batch fermentation of cheese whey," Bioresource Technology, vol. 52, pp. 203-217, 1995.

[15] L. Domingues, P. M. R. Guimarães, and C. Oliveira, "Metabolic engineering of Saccharomyces cerevisiae for lactose/whey fermentation," Bioengineered Bugs, vol. 1, pp. 1-8, 2010. 
[16] L. Domingues, N. Lima, and J. A. Teixeira, "Alcohol production from cheese whey permeate using genetically modified flocculent yeast cells," Biotechnology and Bioengineering, vol. 72, pp. 507-514, 2001.

[17] G. Dragone, S. I. Mussatto, J. M. Oliveira, and J. A. Teixeira, "Characterisation of volatile compounds in an alcoholic beverage produced by whey fermentation," Food Chemistry, vol. 112, pp. 92993, 2009.

[18] A. Paraskevopoulou, I. Athanasiadis, M. Kanellaki, A. Bekatorou, G. Blekas, and V. Kiosseoglou, "Functional properties of single cell protein produced by kefir microflora," Food Research International, vol. 36, pp. 431-438, 2003.

[19] A. Akpinar, "Transformations of fatty acids in filamentous fungi," Ph.D. dissertation, Dept. Biolog. Sci., University of Hull, Hull, UK, 1997.

[20] D. Suddaby, "Essential Fatty Acids: a review of their biochemistry, function, interaction and clinical applications," Croda Universal Ltd., Hull, 1992.

[21] A. Akpinar-Bayizit, "Fungal lipids: The biochemistry of lipid accumulation," International Journal of Chemical Engineering and Applications, vol. 5, pp. 409-414, 2014.

[22] A. Ykema, M. M. Kater, and H. Smit, "Lipid production in whey permeate by an unsaturated fatty acid mutant of the oleaginous yeast Apiotrichum curvatum," Biotechnology Letters, vol. 11, pp. 477-482, 1989.

[23] R. J. Davies, J. E. Holdsworth, and S. L. Reader, "The effect of low oxygen uptake rate on the fatty acid profile of the oleaginous yeast Apiotrichum curvatum," Appl. Microbiol. Biotechnol, vol. 33, pp. $569-57,1990$.

[24] S. Papanikolaou, I. Chevalot, M. Komaitis, G. Aggelis, and I. Marc, "Kinetic profile of the cellular lipid composition in an oleaginous Yarrowia lipolytica capable of producing a cocoabutter substitute from industrial fats," Antonie van Leeuwenhoek, vol. 80, pp. 215-224, 2001.

[25] S. Papanikolaou and G. Aggelis, "Yarrowia lipolytica: a model microorganism used for the production of tailor-made lipids," European Journal of Lipid Science and Technology, vol. 112, pp. 639-654, 2010.

[26] A. Akpinar-Bayizit, L. Yilmaz-Ersan, and T. Ozcan, "Production of single cell oil during growth of Aspergillus species on whey," Joint Annual Meeting of ADSA \& ASAS, July 11-15, Denver, Colorado, USA, Journal of Dairy Science, vol. 93, Suppl 1., p. 608, 2010.

[27] G. Aggelis, R. Ratomahenina, A. Arnaud, P. Galzy et al., "E'tude de l'influence des conditions de culture sur la teneur en acide gamma linole'nique de souches de Mucor," Oléagineux, vol. 43, pp. 311317, 1988.

[28] G. Aggelis, M. Pina, and J. Graille, "Localisation de l'acide gamma linole' nique dans les myce'liums et les spores chez deux Mucorales," Ole'agineux, vol. 45, pp. 229-232, 1990.

[29] L. Hannson and M. Dosta'lek, "Effect of culture conditions on mycelian growth and production of g-linolenic acid by the fungus Mortierella ramanniana," Applied Microbiology and Biotechnology, vol. 28, pp. 240-246, 1988.

[30] H. C. Chen and C. Chang, "Production of g-linolenic acid by the fungus Cunninghamella echinulata CCRC 31840," Biotechnology Progress, vol. 12, pp. 338-341, 1996.

[31] S. Fakas, M. Galiotou-Panayotou, S. Papanikolaou, M. Komaitis, and G. Aggelis, "Compositional shifts in lipid fractions during lipid turnover in Cunninghamella echinulata," Enzyme and Microbial Technology, vol. 40, pp. 1321-1327, 2007.

[32] S. Fakas, S. Papanikolaou, M. Galiotou-Panayotou, M. Komaitis, and G. Aggelis, "Organic nitrogen of tomato waste hydrolysate enhances glucose uptake and lipid accumulation in Cunninghamella echinulata," Journal of Applied Microbiology, vol. 105, pp. 1062 1070, 2008.

[33] S. Fakas, M. C. Ertik, S. Papanikolaou, G. Aggelis et al., "gLinolenic acid production by Cunninghamella echinulata growing on complex organic nitrogen sources," Bioresource Technology, vol. 99, pp. 5986-5990, 2008.

[34] S. Fakas, S. Papanikolaou, A. Batsos, M. Galiotou-Panayotou et al., "Evaluating renewable carbon sources as substrates for single cell oil production by Cunninghamella echinulata and Mortierella isabellina," Biomass and Bioenergy, vol. 33, pp. 573-580, 2009.

[35] S. Fakas, S. Papanikolaou, M. Galiotou-Panayotou, M. Komatis, and G. Aggelis, "Biochemistry and biotechnology of single cell oil," in New Horizons in Biotechnology, A. Pandey, C. Larroche, C. R. Soccol, C. G. Dussard, Eds. AsiaTech Publishers Inc., New Delhi, pp. $52-75,2009$.

[36] S. Fakas, S. Bellou, A. Makri, and G. Aggelis, "Single cell oil and gamma-linolenic acid production by Thamnidium elegans grown on raw glycerol," in Microbial Conversions of Raw Glycerol, G. Aggelis, Ed. Nova Science Publishers Inc., New York, pp. 85-99, 2009.

[37] Y. H. Li, Z. B. Zhao, and F. W. Bai, "High density cultivation of oleaginous yeast Rhodosporidium toruloides Y4 in fed-batch culture," Enzyme and Microbial Technology, vol. 41, pp. 312-317, 2007.

[38] X. Zhao, X. Kong, Y. Hua, B. Feng, and Z. B. Zhao, "Medium optimization for lipid production through co-fermentation of glucose and xylose by the oleaginous yeast Lipomyces starkeyi," European Journal of Lipid Science and Technology, vol. 110, pp. 405-412, 2008

[39] R. Luque, L. Herrero-Davila, J. M. Campelo, J. H. Clark et al., "Biofuels: A technological perspective," Emerging Environmental Technologies, vol. 1, pp. 542-564, 2008.

[40] R. Luque, S. Pinzi, J. M. Campelo, J. J. Ruiz et al., "Biofuels for transport: prospects and challenges," in Emerging Environmental Technologies, V. Shah Ed. vol. 2, Springer, Dordrecht, Heidelberg, London, New York, 2010, pp. 171-210.

[41] A. Kendrick and C. Ratledge, "Lipids of selected molds grown for production of $\mathrm{n}-3$ and $\mathrm{n}-6$ polyunsaturated fatty acids," Lipids, vol. 27, pp. 15-20, 1992.

[42] C. Ratledge, "Single cell oils for the 21st century," in Single cell oils, Z. Cohen, C. Ratledge, Eds. AOCS Press, Champaign, Illinois, 2005 , pp. 1-20.

[43] Z. Wen and F. Chen, "Prospects for eicosapentaenoic acid production using microorganisms," in Single Cell Oils, Z. Cohen, C. Ratledge, Eds. AOCS Press, Champaign, Illinois, 2005, pp. 138-160.

[44] S. L. Pereira, Y. S. Huang, E. G. Bobik et al.,"A novel omega3-fatty acid desaturase involved in the biosynthesis of eicosapentaenoic acid," Biochemical Journal, vol. 378, pp. 665-671, 2004

[45] J. Folch, M. Lees, and G. H. S. Stanley, "A Simple method for the isolation and purification of total lipids from animal tissues," J Biol Chem., vol. 226, pp. 497-509, 1957.

[46] IUPAC " International Union of Applied and Pure Chemistry method Commission Regulation (EC)," No 796/2002 of 6 May, 2002.

[47] R. J. Davies, Food Technology, vol. 6, pp. 33-37, 1984.

[48] R. J. Davies, "Yeast oil from cheese whey - process development," in Single Cell Oil, R. S. Moreton, Ed. John Wiley and Sons, Inc., New York, N.Y., 1988, pp. 99-146.

[49] R. J. Davies, "Scale up of yeast oil technology," in Industrial Applications of Single Cell Oils D. J. Kyle and C. Ratledge, Eds. pp. 196-218, American Oil Chemists' Society, Champaign, IL, USA, 1992.

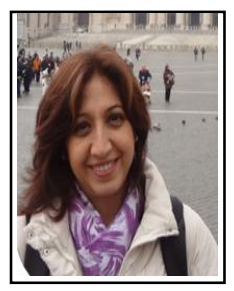

Arzu Akpinar-Bayizit is an assistant professor at the Department of Food Engineering, Uludag University, Bursa/Turkey. After having M.Sc. degree at Uludag University in 1994, she had her Ph.D. degree at the Department of Biological Sciences of the University of Hull, United Kingdom, in 1997. The topic of her $\mathrm{Ph} . \mathrm{D}$ project funded by Higher Education Council of Turkey was on fungal lipid metabolism, subsequently a novel hydroxylated fatty acid was identified from the sewage fungus, Leptomitus lacteus. The main lectures given by Mrs. Akpinar-Bayizit are instrumental analysis, microbial process technology, food fermentations and functional foods. Her research interests include fermentation technology, particularly microbial fermentations, and lipid technology. To date she has supervised 6 M.Sc. studies, and supervising ongoing 5 M.Sc. and $3 \mathrm{Ph} . \mathrm{D}$. projects. She has published several research and review articles in international journals and has two book chapters.

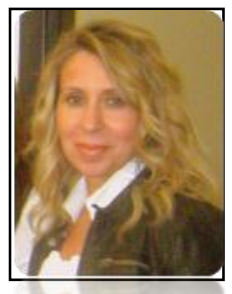

Tulay Ozcan is an associate professor of Department of Food Engineering at the Uludag University, Bursa Turkey. More recently, she has worked in the area of rheology and texture of dairy products. From 2005 to 2006 and 2010 (21 months) she worked at University of Wisconsin-Madison USA, Department of Food Science as a visiting scientist. Her research interests include dairy chemistry and biochemistry, rheological properties and microstructure of yogurt, texture of yogurt and cheese, the use of dairy and plant based proteins for the production of functional dairy products, probiotics and prebiotics, traditional cheeses and enzyme accelerated ripening of cheese, the use of fat replacer in dairy products and principles of nutrition. 


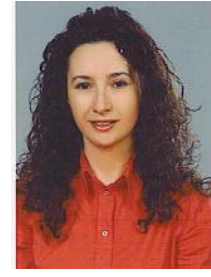

Lutfiye Yilmaz-Ersan is an associate professor of the Department of Food Engineering at the Uludag University, Bursa, Turkey. More recently, she has worked dairy and dairy products. From 2007 to 2008 (14 months) she worked at University of NebraskaLincoln USA, Department of Food Science and Technology as a visiting scientist. Her research interests include dairy and dairy products, probiotics and prebiotics.

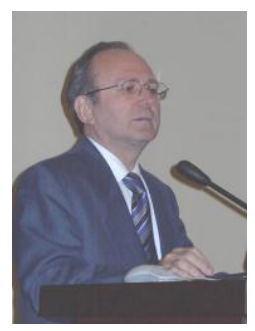

Fikri Basoglu is a professor at the Department of Food Engineering, Uludag University, Bursa/Turkey. He had his M.Sc. degree at Ankara Univerity on Food Microbiology on 1976 and Ph.D degree at the Department of Food Science and Technology of the Ankara University on 1981. The topic of his $\mathrm{Ph} . \mathrm{D}$. project was on TAG and fatty acid profiles of Turkish olive oils. His research interests include food microbiology and edible fats and oils. 